\title{
SOIL CARBON STOCKS CULTIVATED WITH COFFEE IN THE BRAZILIAN SAVANNA: EFFECT OF CULTIVATION TIME AND USE OF ORGANIC COMPOST
}

\author{
Maísa Honório Belizário ${ }^{1}$, Gregori da Encarnação Ferrão², Carlos Clemente Cerri ${ }^{3} \dagger$, \\ Marcos Siqueira-Neto ${ }^{4}$
}

(Received: December 5, 2016; accepted: Tuesday, April 25, 2017)

\begin{abstract}
Land-use change (LUC) is one of the main responsible for the loss of soil organic matter (SOM) in the form of $\mathrm{CO}_{2}$ to atmosphere. The aims of the present study were i) evaluate soil $\mathrm{C}$ stocks due to coffee cultivation time after LUC and ii) evaluate the use of the organic compost from the by-product of bean processing as a source of SOM. The study was performed in dystrophic red latosol in the municipality of Patrocínio, MG, Brazil. Two evaluations were performed; i) three coffee (Coffea arabica L. var. Icatú Vermelho) growing areas with different implantation times $(8,15$ and 37 years) in relation to Cerrado stricto sensu (reference); and ii) area cultivated with coffee (C. arabica var. Bourbon Vermelho) that received organic compost for four years. Soil was sampled in layers $0-5,5-10$ and 10-20 cm. In the first study, the $C$ stock $(0-20 \mathrm{~cm})$ was higher under native vegetation $\left(67 \mathrm{Mg} \mathrm{C}^{-1}\right)$ in relation to the coffee growing $\left(63 \mathrm{Mg} \mathrm{C}^{-1}\right)$, however, did not differ significantly and showed subtle loss rates of $0.12 ; 0.06$ and $0.02 \mathrm{Mg} \mathrm{Cha}^{-1}$ year $^{-1}$ for 8,15 and 37 years, respectively. In the second study, the organic compost applied to the soil increased the $\mathrm{C}$ stock $(0-20 \mathrm{~cm})$ to $4.6 \mathrm{Mg} \mathrm{C}$ ha ${ }^{-1}$ and showed an accumulation rate of 1.15 $\mathrm{Mg} \mathrm{C} \mathrm{ha}{ }^{-1}$ year $^{-1}$. Thus, it is concluded that $\mathrm{C}$ stocks is reduced in the soil due to LUC, however, the application of organic compost increased the supply of organic material, favoring the maintenance and even increasing the stock in the soil.
\end{abstract}

Index terms: Coffee growing time, C. arabica (L.) var. Icatú Vermelho, C. arabica (L.) var. Bourbon Vermelho, organic compost, Cerrado biome.

\section{ESTOQUES DE CARBONO DO SOLO CULTIVADO COM CAFÉ NO CERRADO: EFEITO DO TEMPO DE CULTIVO E USO DE COMPOSTO ORGÂNICO}

RESUMO: A mudança de uso da terra (MUT) é um dos principais responsáveis pela perda de matéria orgânica do solo (MOS) na forma de $\mathrm{CO}^{2}$ para atmosfera. Os objetivos deste estudo foram; i) avaliar os estoques $\mathrm{C}$ do solo devido ao tempo cultivo de café após a MUT e; ii) avaliar o uso do composto orgânico, oriundo do subproduto do beneficiamento dos grãos como fonte de MOS. O estudo foi realizado em Latossolo Vermelho distrófico em Patrocínio (MG). Duas avaliações foram realizadas; i) avaliaram-se três áreas cultivadas com café (Coffea arabica L. var Icatú vermelho) com diferentes tempos e implantações (8, 15 e 37 anos) comparadas ao Cerrado stricto sensu (referência) e; ii) avaliou-se área cultivada com café (C. arabica L. var Bourbon vermelho) que recebeu durante quatro anos o composto orgânico. O solo foi amostrado nas camadas 0-5, 5-10 e 10-20 $\mathrm{cm}$. No primeiro estudo, o estoque de $\mathrm{C}(0-20 \mathrm{~cm})$ foi maior no Cerrado $(67 \mathrm{Mg} \mathrm{C}$ ha-1) comparado ao cultivo do café $(63 \mathrm{Mg}$

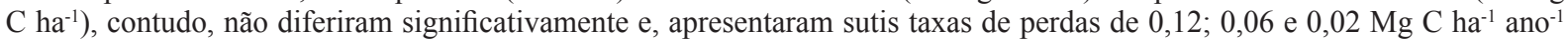
para 8, 15 e 37 anos, respectivamente. No segundo estudo o composto orgânico aplicado ao solo aumentou o estoque de C ( $0-20$ $\mathrm{cm}$ ) em 4,6 Mg C ha ${ }^{-1}$ e, apresentou taxa de acúmulo de 1,15 $\mathrm{Mg} \mathrm{C} \mathrm{ha}^{-1} \mathrm{ano}^{-1}$. Assim conclui-se que a MUT promove a redução nos estoques de $\mathrm{C}$ no solo, contudo, a aplicação de composto orgânico aumentou a oferta de material orgânico favorecendo a manutenção e, até mesmo aumentando o estoque no solo.

Termos para indexação: Tempo de cultivo do café, C. arabica (L.) var. Icatú vermelho, C. arabica (L.) var. Bourbon vermelho, composto orgânico, Bioma Cerrado.

\section{INTRODUCTION}

Coffee represents more than $8 \%$ of the world's permanent crops, with more than 10 million hectares of land dedicated to its production. It is one of the most traded commodities, sustaining the income of about 25 million people (FOOD AND AGRICULTURE ORGANIZATION OF THE UNITED NATIONS - FAO, 2016). Currently, there are in Brazil approximately 280 thousand producers and the 2016 harvest had more than 2 million hectares $(\sim 3 / 4$ Coffea arabica) with production of 50 million $(\sim 80 \% \quad C$. arabica $)$ processed bags (COMPANHIA NACIONAL DE ABASTECIMENTO - CONAB, 2016).

The expansion of Brazilian coffee production in the Alto Parnaíba region of Minas Gerais state, Brazil, occurred in areas previously occupied by native vegetation of the Cerrado biome. Land-use change (LUC) comprises the

\footnotetext{
${ }^{1,4}$ Center of Nuclear Energy in Agriculture - University of São Paulo (CENA/USP) - Laboratory of Environmental Biogeochemistry - Av. Centenário, 303 -13.400-970 - São Dimas - Piracicaba - SP - maisaufla@yahoo.com.br, msiqueir@usp.br ${ }^{2}$ Center of Agricultural and Environmental Sciences - Federal University of Maranhão (CCAA/UFMA) - Laboratory of Plant Ecophysiology - Br. 222 km 04 s/n - 65.500-000 - Boa Vista - Chapadinha - MA - gregoriferrao@yahoo.com.br

${ }^{3 \dagger}$ In memorian
} 
conversion of areas with native vegetation to productive systems and is the main responsible for the change in soil organic matter (SOM) dynamics and changes in soil carbon (C) stock (LAL, 2008).

When considering only the topsoil, the $\mathrm{C}$ stock ( $\sim 800 \mathrm{Pg}$ of $\mathrm{C})$ corresponds almost to the same amount present in the atmosphere (CERRI et al., 2009). During the conversion process from natural ecosystems to agricultural ones, losses occurring in $\mathrm{C}$ stocks-SOM promote the $\mathrm{C}-\mathrm{CO}_{2}$ transfer to the atmosphere (LAL, 2007).

The loss of soil $\mathrm{C}$ can be attributed to the reduced organic material inputs, the increased decomposition rate of plant residues and the effects of management practices that can reduce the physical protection of the SOM in soil aggregates (CERRI et al., 2009; LAL, 2008). Thus, the mineralization rate of the different $\mathrm{C}$ compartments in the soil is increased as a function of the interactions with the promoted changes in the chemical, physical and biological attributes of soil (LAL, 2008).

According to Karp et al. (2015), after loss of C soil stock due to LUC, the recovery capacity of the SOM can be between 25 and $50 \%$ lower than the initial amount. However, the recovery potential is related to the history of the area, the environmental conditions related to climate (BERNOUX et al., 2006) and soil type (SIQUEIRA NETO et al., 2010), management (BAYER et al. , 2006), besides especially the time and maintenance of the system (CORBEELS et al., 2016).

A study performed in Brazil with the coffee crop indicated a $33 \%$ reduction in soil C when compared with native vegetation in the $0-10 \mathrm{~cm}$ layer, as well as significant changes in the environmental services, in the functions and quality of the SOM (MARCHIORI JÚNIOR; MELO, 2000). On the other hand in the study by Pavan and Chaves (1996), the higher the planting density of the coffee plantation, the higher the soil C stock. Whereas the results found by Rangel et al. (2008), the soil C stock was not altered by the spacing between the plants. Additionally, in interline of the coffee plantation were found values of $\mathrm{C}$ stock similar to the verified in the crown projection.

The studies that evaluate soil $\mathrm{C}$ stocks in the coffee crop are scarce and present quite contrasting results in the literature due to natural factors (climate, soil, relief, cultivation area, etc.) and variety of management (species, cultivars, spacing, pruning, irrigation, use of correctives and fertilizers, etc.). Moreover, given the growing international requirements for sustainable crops based on product life-cycle analyses, the economic, social and even historical-political importance of culture are considered. In this way, the hypothesis of this study was that the cultivation time after LUC, as well as the supply of organic material in crop management can recover (totally or partially) the $\mathrm{C}$ stocks of coffee plantations in the Cerrado biome. The objective was to evaluate the influence on soil $\mathrm{C}$ due to the coffee cultivation time after the LUC in the Cerrado biome and to evaluate the use of the organic compost (processed by-product of beans) as a source of organic material in the coffee crop management.

\section{MATERIAL AND METHODS}

\section{Characterization of study areas}

The sampled areas are located in Boa Vista Farm, at Rodovia MG 188, km 16, rural area of the municipality of Patrocínio, Minas Gerais state, Brazil. The climate is type Cwa (Köppen classification) - high-altitude humid subtropical, with temperature between $7{ }^{\circ} \mathrm{C}$ and $35^{\circ} \mathrm{C}$ and rainfall above $1,300 \mathrm{~mm}$. The soil was classified as dystrophic red latosol (EMPRESA BRASILEIRA DE PESQUISA AGROPECUÁRIA - EMBRAPA, 2013).

The first study evaluated three coffee (Coffea arabica L. var. Icatú Vermelho) growing areas with different implantation ages, being 8,15 and 37 years after native vegetation conversion. For reference, a legal reserve area was taken with approximately 4 ha composed of native vegetation contiguous to the coffee growing areas. The area with native vegetation was classified as Cerrado stricto sensu, even with signs of degradation (BASTOS; FERREIRA, 2012).

The conversion of native vegetation to coffee cultivation was performed by cutting and burning the vegetation. Briefly, trees with potential for exploitation were removed, such as posts or for coal manufacturing. Then, the remaining phytomass was felled using two tractors with a chain attached to them. The fallen material remained on the ground until dry, when it was "windrowed" (formation of piles with dry plant material) and burned. After the second "windrowing" and burning of the remaining plant material, the area was prepared using deep plowing $(\sim 30 \mathrm{~cm})$ and the manual harvesting of remaining stems and roots of larger diameter. Approximately 
six months before planting of coffee seedlings, the first soil correction with dolomitic limestone $(\sim 2$ $\mathrm{Mg} \mathrm{ha}{ }^{-1}$ ) was performed with a leveling harrow. After this period, grooves were opened with application of natural phosphate and nitrogen and potassium fertilizer, as recommended by soil analysis and subsequent planting of seedlings.

\section{Evaluation of soil C stocks}

The selected areas to evaluate the effect of coffee cultivation time have 10.1, 5.9 and 13.8 ha, respectively for the times 8,15 and 37 years, spacing of $3.8 \times 0.6 \mathrm{~m}$, the management of spontaneous vegetation between the lines was performed through brushcutter four times a year. The physical-chemical characterization of the soil in these areas is shown in Table 1.

The second study evaluated the effect of the organic compost application in an area of 10.1 ha cultivated for 12 years with coffee (C. arabica var. Bourbon Vermelho) with spacing of $4.0 \times 0.5 \mathrm{~m}$, which in the last four years received $5 \mathrm{Mg} \mathrm{ha}^{-1}$ year ${ }^{1}$ of organic compost in approximately one third of the total cultivated area (3.42 ha). In the total area, the control of the spontaneous vegetation was performed with brushcutter four times a year and brushing (collecting the plant residues from the soil surface in the crown projection of plants) in the period prior to harvesting. The physical- chemical characterization of the soil in these areas is shown in Table 2.

The applied organic compost was composed of coffee husks after the wet fruit processing, coffee husk after processing of beans and crushed plant residues derived from pruning, these materials were mixed and remained in the barnyard at rest for a period between six and eight months until application in the field. The compost was always applied in the crown projection of plants. The characterization of the organic compost is presented in Table 3.

\section{Soil sampling and laboratory analyses}

Soil samples were collected at 15 random points in the areas without line discrimination (crown projection) or between the lines of the coffee plantation. At each point, undisturbed samples were collected with a $5 \times 5 \mathrm{~cm}\left(99.4 \mathrm{~cm}^{-3}\right)$ stainless steel cylinder in the layers 0-5, 5-10 and $10-20 \mathrm{~cm}$. In the Laboratory of Environmental Biogeochemistry (CENA - USP), samples were weighed (total mass), then air dried and passed through a $2 \mathrm{~mm}$ sieve. Bulk density (Bd) was determined after discarding the gravimetric moisture in $5 \mathrm{~g}$ aliquots of soil, dried for 48 $\mathrm{h}$ in ovens at $105{ }^{\circ} \mathrm{C}$. The total $\mathrm{C}$ content was determined in the elemental analyzer $\mathrm{LECO}^{\circ} \mathrm{CN}$ $2000^{\circledR}$ (St. Joseph, Michigan).

TABLE 1 - Physical and chemical characterization of the soil for the 0-20 cm layer of the savanna native vegetation and cultivated with coffee aged 8, 15 and 37 years at Boa Vista Farm in the municipality of Patrocínio, Minas Gerais state, Brazil.

\begin{tabular}{|c|c|c|c|c|c|c|c|c|}
\hline \multirow{2}{*}{ Areas } & $\mathrm{pH}$ & Clay & avail.-P & $\mathrm{K}^{+}$ & $\mathrm{Ca}^{2+}$ & $\mathrm{Mg}^{2+}$ & $\mathrm{E}$ & \multirow{2}{*}{$\begin{array}{c}\mathrm{BS} \% \\
\%\end{array}$} \\
\hline & $\mathrm{CaCl}_{2}$ & $\mathrm{~g} \mathrm{~kg}^{-1}$ & $\mathrm{mg} \mathrm{dm}^{-3}$ & \multicolumn{4}{|c|}{$\mathrm{mmol}_{\mathrm{c}} \mathrm{dm}^{-3}$} & \\
\hline Cerrado & 4.4 & 485.3 & 2.3 & 1.2 & 2.1 & 1.6 & 61.1 & 8.0 \\
\hline Coffee 8 years & 5.3 & 507.4 & 17.9 & 2.7 & 22.8 & 10.2 & 69.9 & 51.1 \\
\hline Coffee 15 years & 5.9 & 514.6 & 22.3 & 3.5 & 24.6 & 13.6 & 73.9 & 56.4 \\
\hline Coffee 37 years & 5.3 & 513.9 & 34.4 & 4.4 & 23.3 & 14.8 & 73.9 & 57.5 \\
\hline
\end{tabular}

avail.-P = available phosphorus; $\mathrm{E}=$ potential cation exchange capacity; $\mathrm{BS} \%$ = base saturation.

TABLE 2 - Physical chemical characterization of the soil for the 0-20 $\mathrm{cm}$ layer of the areas with and without organic compost application cultivated with coffee at Boa Vista Farm in the municipality of Patrocínio, Minas Gerais state, Brazil.

\begin{tabular}{|c|c|c|c|c|c|c|c|c|}
\hline \multirow{2}{*}{ Area } & $\mathrm{pH}$ & Clay & avail.-P & $\mathrm{K}^{+}$ & $\mathrm{Ca}^{2+}$ & $\mathrm{Mg}^{2+}$ & $\mathrm{E}$ & $\mathrm{BS} \%$ \\
\hline & $\mathrm{CaCl}_{2}$ & $\mathrm{~g} \mathrm{~kg}^{-1}$ & $\mathrm{mg} \mathrm{dm}^{-3}$ & \multicolumn{4}{|c|}{$\mathrm{mmol}_{\mathrm{c}} \mathrm{dm}^{-3}$} & $\%$ \\
\hline Without compost & 5.2 & 596.3 & 26.4 & 2.7 & 22.3 & 11.8 & 76.5 & 48.1 \\
\hline With compost & 5.5 & 595.7 & 32.5 & 3.4 & 27.9 & 14.7 & 81.3 & 56.6 \\
\hline
\end{tabular}

avail.-P = available phosphorus; $\mathrm{E}=$ potential cation exchange capacity; $\mathrm{BS} \%$ = base saturation. 
TABLE 3 - Chemical characterization of the organic compost applied in the area cultivated with coffee at Boa Vista Farm in Patrocínio, MG, Brazil.

\begin{tabular}{lc}
\hline Properties & Content $\left(\mathrm{g} \mathrm{kg}^{-1}\right)$ \\
\hline Total carbon & 419.6 \\
Total nitrogen & 9.0 \\
C:N ratio & 46.6 \\
Phosphorus $\left(\mathrm{P}_{2} \mathrm{O}_{5}\right)$ & 0.4 \\
Potassium $\left(\mathrm{K}_{2} \mathrm{O}\right)$ & 2.1 \\
Calcium & 3.8 \\
Magnesium & 0.9 \\
Sulfur & 0.9 \\
\hline
\end{tabular}

\section{Statistical calculations and analyses}

The $\mathrm{C}$ stocks were calculated from the total $\mathrm{C}$ contents, the bulk density values and the sampled soil layers, following Equation 1 presented by Bernoux et al. (1998):

$$
S=B d \times h \times C
$$

where $\mathrm{S}$ is the soil carbon stock converted into hectare $\left(\mathrm{Mg} \mathrm{ha}^{-1}\right) ; B d$, bulk density $\left(\mathrm{g} \mathrm{cm}^{-3}\right)$; $h$, the thickness of the sampled layer $(\mathrm{cm})$; and $C$, the soil $\mathrm{C}$ content $\left(\mathrm{g} \mathrm{kg}^{-1}\right)$.

The C stocks were corrected for the soil mass of the reference area (Cerrado), since the bulk density between the coffee cultivated areas showed a significant difference in relation to the area with native vegetation. However, it was not necessary to correct the values for the second study, since no significant differences were found among the bulk density values. The calculation used for correction was presented by Fernandes and Fernandes (2013) (Eq. 2):

$$
S_{c}=\Sigma^{n-i} S+\left\{M_{a i}-\left(\Sigma^{n} M_{a}-\Sigma^{n} M_{r}\right) C_{i}\right\}
$$

where $S$ is the $\mathrm{S}$ stock corrected by the soil mass $\left(\mathrm{Mg} \mathrm{ha}^{-\mathrm{q}}\right) ; \Sigma_{n i} S$ is the sum of the layer stocks, without the last sampled layer; $M_{q i}$ is the soil mass of the last sampled soil layer; $\Sigma^{n} M^{i}$ is the sum of the total mass of sampled soil; $\Sigma^{n} M_{r}$ is the sum of the reference soil mass; and $C_{i}$ is the $\mathrm{C}$ content in the last sampled layer.

The annual rate of change in soil $\mathrm{C}$ stock was estimated based on changes in $\mathrm{C}$ stocks over time in relation to the reference area (Eq. 3).

$$
\Delta S=\frac{\sum\left(S_{f}(A)-S_{i}(A)\right)}{T}
$$

where: $\Delta S$ is the soil $\mathrm{C}$ stock variation $\left(\mathrm{Mg} \mathrm{ha}^{-1}\right.$ year-1 $) ; A$ is considered as the evaluated system; $S_{f}(A)$ is the C stock at the final time (Mg C) of the system $A ; S_{i}(A)$ is the C stock at the initial time $(\mathrm{Mg} \mathrm{C})$ in the reference area; and $T$ is the time (years).

The results of the first and second study were compared separately. The results were subjected to analysis of variance (ANOVA) in order to obtain the significant differences by the ANOVA procedure and the averages were compared by Tukey test at 5\% probability level to characterize the differences among the sampled areas.

In the first study, the bulk density was compared for the $\mathrm{C}$ stock correction by the soil mass of the reference area (Cerrado), as well as to determine the least significant difference (LSD) among the $\mathrm{C}$ contents at each layer and the comparison among corrected $\mathrm{C}$ stocks between the different coffee cultivation times $(8,15$ and 37 years) and the reference area (native vegetation). In the second study, the results of bulk density, the determination of the LSD among the C contents at each layer and the comparison between the corrected C stocks between the area with compost application and the reference area, i.e. without compost application.

\section{RESULTS AND DISCUSSION}

\section{Soil carbon content}

The soil C contents for both studies showed the highest values in the top layer, decreasing with increasing depth (Figure 1A and B). 


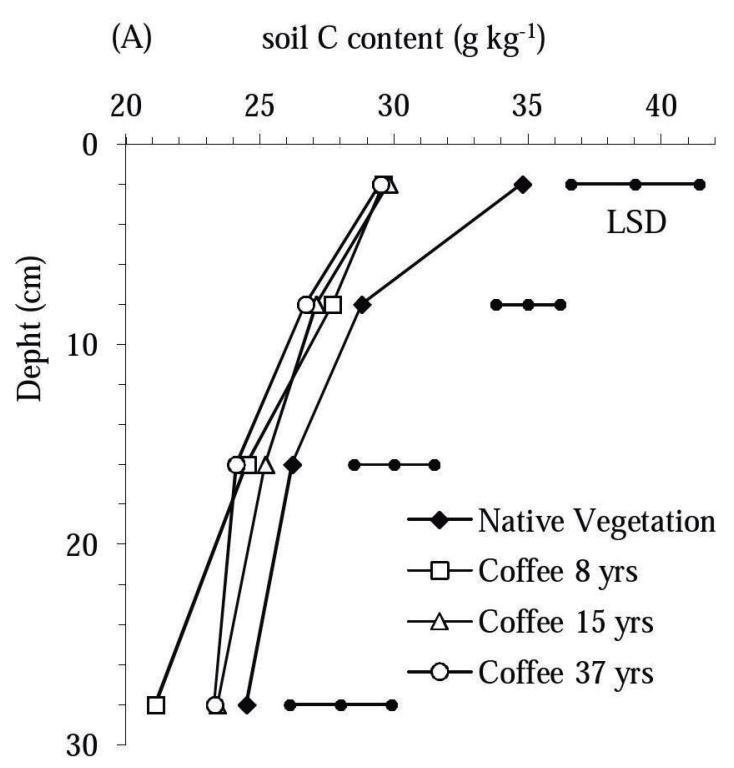

(B) soil C content $\left(\mathrm{g} \mathrm{kg}^{-1}\right)$

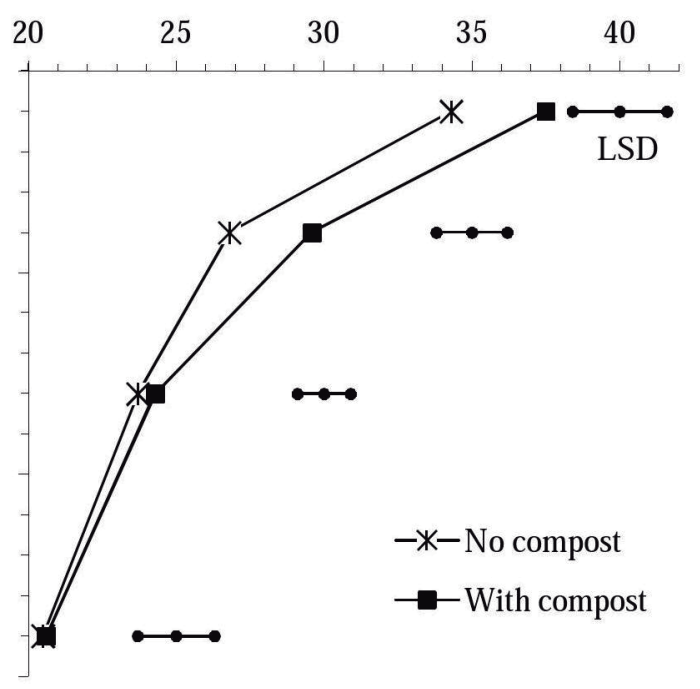

FIGURE 1 - Carbon contents $\left(\mathrm{g} \mathrm{kg}^{-1}\right)$ in the $0-20 \mathrm{~cm}$ soil layer (A) for the Cerrado and in areas with different coffee cultivation times; (B) without and with application of the organic compost at Boa Vista Farm in the municipality of Patrocínio, Minas Gerais state, Brazil. Values represent the average $(n=15)$; the horizontal bars represent the least significant difference $(\mathrm{LSD})$ obtained in the Tukey test $(\mathrm{p}<0.05)$.

This behavior is characteristic of latosols in which there is no constant turnover from the topsoil (SIQUEIRA NETO et al., 2010).

The maintenance of high $\mathrm{C}$ contents in the top layer is justified by the deposition/contribution of organic materials on the soil surface. This contribution is due to the fall of leaves, both by the coffee and by the savanna vegetation, as well as by the renovation of the root system of plants that usually show greater biomass in the soil surface, searching for elements derived from the nutrient cycling. In coffee growing areas, there is still the deposition of the organic material from the spontaneous vegetation between the rows of crop, ploughed periodically. Alcântara and Ferreira (2000), in an experiment with 18 years of data collection, observed that the spontaneous vegetation, always ploughed in the coffee between the lines of the coffee increased the SOM and improved its soil physical and chemical attributes.

In a study performed by Siles, Harmand and Vaast (2010), 50\% biomass of fine roots were found in the first $30 \mathrm{~cm}$ of soil and, therefore, the $\mathrm{C}$ contribution by the roots can be up to $30 \%$ higher in relation to the contribution of the shoot deposition. According to the authors, this occurs because biomass of the root system shows residence time 2.4 times higher than the $\mathrm{C}$ derived from the shoot.
In the study of the effect of coffee cultivation time in relation to native vegetation (Figure 1A), the highest $\mathrm{C}$ contents were verified in the Cerrado $(\mathrm{p}<0.05)$, mainly in the topsoil $(0-5 \mathrm{~cm})$ while the different times of coffee implantation did not show significant difference in soil $\mathrm{C}$ contents $(p>0.05)$.

Regarding the study that evaluated the effect of the organic compost application (Figure 1B), the soil C contents for the $0-10 \mathrm{~cm}$ layer were significantly higher with the compost application $(\mathrm{p}<0.05)$ however there was no significant difference $(\mathrm{p}>0.05)$ for the $10-20 \mathrm{~cm}$ layer.

\section{Bulk density}

The lowest soil density values were verified in the Cerrado (Table 4), while significantly higher density values were observed for coffee with 8 and 15 years of implantation. On the other hand, the lowest density among coffee growing areas was verified in the area with 37 -year coffee $\left(0.96 \mathrm{~g} \mathrm{~cm}^{-3}\right)$. In the $10-20 \mathrm{~cm}$ layer, there was no difference among the coffee growing areas, regardless of the implantation time of the culture.

The cultivation time was a favorable factor for this parameter probably due to the high volume of fine roots present in older coffee plantations, thus providing greater soil aggregation and hence better structure and porosity. 
TABLE 4 - Average bulk density $\left(\mathrm{g} \mathrm{cm}^{-3}\right)$ for Cerrado and in areas with different coffee cultivation times at Boa Vista Farm in the municipality of Patrocínio, Minas Gerais state, Brazil.

\begin{tabular}{lccc}
\hline \multirow{2}{*}{ Area } & \multicolumn{3}{c}{ Bulk density $\left(\mathrm{g} \mathrm{cm}^{-3}\right)^{\dagger}$} \\
\cline { 2 - 4 } & $0-5 \mathrm{~cm}$ & $5-10 \mathrm{~cm}$ & $10-20 \mathrm{~cm}$ \\
\hline Cerrado & $0.97 \mathrm{~b}$ & $1.00 \mathrm{~b}$ & $0.99 \mathrm{~b}$ \\
Coffee 8 & $1.02 \mathrm{a}$ & $1.05 \mathrm{a}$ & $1.06 \mathrm{a}$ \\
Coffee 15 & $1.03 \mathrm{a}$ & $1.07 \mathrm{a}$ & $1.05 \mathrm{a}$ \\
Coffee 37 & $0.96 \mathrm{~b}$ & $1.04 \mathrm{ab}$ & $1.04 \mathrm{a}$ \\
\hline
\end{tabular}

${ }^{\dagger}$ Average values of bulk density $(n=15)$ followed by the same letter among the different coffee cultivation times and Cerrado did not show statistically significant difference by Tukey test $(p<0.05)$.

The bulk density is influenced by SOM, since this is the greatest conditioning agent of soil physical attributes such as aggregation and aeration (SILVA et al., 2006).

In the study with and without organic compost application, no significant difference $(p>$ 0.05 ) was observed among the bulk density for the sampled layers (Table 5).

In general, in different coffee growing areas, for soils from the Cerrado, the values verified in the literature were well above the verified in the present study. Cortez et al. (2010) found values between 1.71 and $1.76 \mathrm{~g} \mathrm{~cm}^{-3}$ for the coffee cultivated in soil from the Cerrado biome, while Alcântara and Ferreira (2000), in a long-term experiment using brushcutter to control invasive plants in the interlines, showed values between 1.29 and $1.41 \mathrm{~g} \mathrm{~cm}^{-3}$. Silva et al. (2006) obtained values from 1.38 to $1.55 \mathrm{~g} \mathrm{~cm}^{-3}$ in coffee area with application of herbicides to control invasive plants between the lines.

\section{Soil C stocks}

Soil C stocks for the $0-20 \mathrm{~cm}$ layer between the native vegetation area and the cultivated areas with different coffee implantation times did not differ significantly $(\mathrm{p}>0.05)$. However, it is possible to verify lower average values in the $\mathrm{C}$ stocks with the increase of coffee cultivation time (Figure 2A).

The shrub vegetation, typical from the Cerrado biome, mainly with plants physiognomy is characterized by a low ratio between the shoot and the root system, i.e., these types of plants have a woody, robust and abundant root system, precisely adapted to the occurrence systemic natural fires (GRACE et al., 2006) and lack of water. In this way, the occurrence of burning of the natural vegetation and subsequent deposition of the partially burned material and coal fragments in a natural ecosystem, i.e., without soil turnover, allows a large quantity of fragmented organic material with a high $\mathrm{C}: \mathrm{N}$ ratio remaining in the soil (CORBEELS et al., 2016). This cycle, repeated for a long time, leads to physical and chemical (humification) and microbiological (decomposition/mineralization) transformation processes in this organic material and hence the $\mathrm{C}$ accumulation in the form of SOM.

In areas with different coffee cultivation times, the lower average values of $\mathrm{C}$ stocks may be related to the SOM loss of the conversion process from native vegetation to agricultural system. The phytomass was initially discharged and burned during the conversion of areas, then the deep soil turnover was performed in several operations and finally the inputs (i.e. limestone and fertilizer) were applied. This sequence of operations is quite aggressive to the soil and hence tends to reduce the content of SOM (PAUSTIAN et al., 2016).

Moreover, it should not also be disregarded that after LUC operations, the coffee cultivation, due to its perennial nature, does not require constant soil turnovers, as occurs in annual crops. Thus, the development of root system of the crop, as well as the spontaneous vegetation between the lines of cultivation can provide conditions for a new arrangement of the soil minerals and formation of new macro-aggregates and hence the soil and porosity restructuring. Not only due to the root system, but also to the contribution of leaves and branches of the plants and the phytomass contribution of the spontaneous vegetation, ploughed periodically. 
TABLE 5 - Average bulk density $\left(\mathrm{g} \mathrm{cm}^{-3}\right)$ for the area without and with organic compost application at Boa Vista Farm in the municipality of Patrocínio, Minas Gerais state, Brazil.

\begin{tabular}{lccc}
\hline \multirow{2}{*}{ Area } & \multicolumn{3}{c}{ Bulk density $\left(\mathrm{g} \mathrm{cm}^{-3}\right)^{\dagger}$} \\
\cline { 2 - 4 } & $0-5 \mathrm{~cm}$ & $5-10 \mathrm{~cm}$ & $10-20 \mathrm{~cm}$ \\
\hline Without compost & $1.00^{\mathrm{ns}}$ & $1.06^{\mathrm{ns}}$ & $1.05^{\mathrm{ns}}$ \\
With compost & 0.98 & 1.06 & 1.06 \\
\hline $\begin{array}{l}{ }^{\dagger} \text { Average values of bulk density }(\mathrm{n}=15) \text { without and with organic compost application did not show statistically } \\
\text { significant difference by Tukey test }(p<0.05) ; \mathrm{ns}=\text { not significant. }\end{array}$
\end{tabular}

(A)

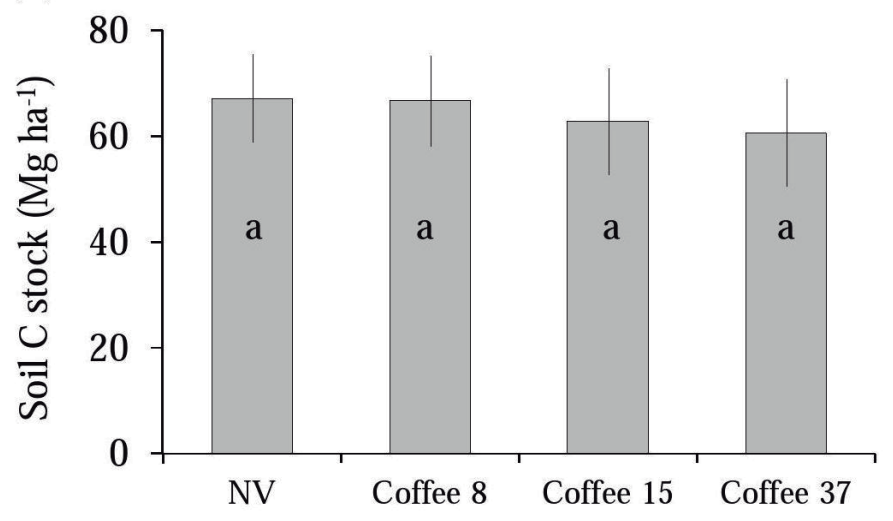

(B)

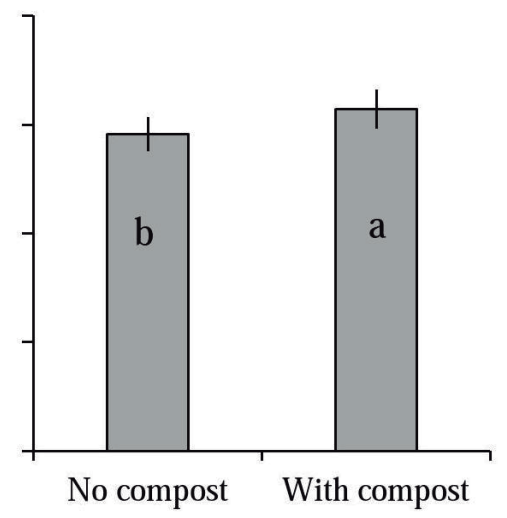

FIGURE 2 - Carbon stocks $\left(\mathrm{Mg}^{-1}\right)$ in the 0-20 $\mathrm{cm}$ soil layer (A) for the Cerrado and in areas with different coffee cultivation times; (B) without and with application of the organic compost at Boa Vista Farm in the municipality of Patrocínio, Minas Gerais state Brazil. Values represent the average $(n=15) \pm$ standard deviation; the same lowercase letters within each study did not differ significantly by Tukey test $(\mathrm{p}<0.05)$.

In the study performed by Marchiori Junior and Melo (2000), the layers $0-10$ and $10-20 \mathrm{~cm}$ were reduced by 33 and $10 \%$, respectively, in the soil $\mathrm{C}$ stock cultivated with coffee for 18 years in relation to the native vegetation cover. On the other hand, the results found by Grebim (2010), evaluating the $\mathrm{C}$ stock in coffee crops with 10 and 30 years in Cerrado biome soils, observed an increase of 25 and $43 \%$ in relation to the native vegetation. Rangel et al. (2008) observed that the coffee cultivation for 11 years led to increased $\mathrm{C}$ stocks in the planting line, however, they observed a reduced crown projection of the coffee plantation. These results, when integrated by area and compared to the native vegetation, did not show significant difference.

In the study by Hergoualc'h et al. (2012), a stock of $\mathrm{C}$ above $100 \mathrm{Mg} \mathrm{ha}^{-1}$ was verified in the $0-40 \mathrm{~cm}$ layer in coffee grown under conventional system, i.e., using brushcutter in the management of invasive plants in the interline. This result, when compared to coffee cultivation under agroforestry system, showed a significant difference only in the $0-10 \mathrm{~cm}$ layer $\left(+2.4 \mathrm{Mg} \mathrm{ha}^{-1}\right)$, which was not significant for the whole sampled layer. In this same study, the authors report that the coffee crop stored in the litter and in the root system approximately $6 \mathrm{Mg} \mathrm{ha}^{-1}$ of $\mathrm{C}$, which later will be decomposed and partly incorporated in the soil. The highest C loss rate in the soil, even without significant differences in relation to Cerrado, was verified in the area cultivated for eight years $\left(-0.12 \mathrm{Mg} \mathrm{C} \mathrm{ha}^{-1}\right.$ year $\left.{ }^{-1}\right)$ which was exponentially decreasing over the years (Figure $3)$. Therefore, after 15 years of cultivation, the rate was $-0.06 \mathrm{Mg} \mathrm{C}^{-1} \mathrm{year}^{-1}$ and $-0.02 \mathrm{Mg} \mathrm{C} \mathrm{ha}^{-1}$ year ${ }^{-1}$ after 37 years.

In a study performed on coffee crops in Costa Rica, Hergoualc'h et al. (2012) verified reduction in soil C stock of $-0.43 \mathrm{Mg} \mathrm{C}^{-1}$ year $^{-1}$ for coffee under conventional management with three years. On the other hand, the C stock for coffee in an agroforestry system showed a small accumulation rate of $0.09 \mathrm{Mg} \mathrm{C}^{-1}$ year $^{-1}$. However, Guimarães et al. (2014) found increments by 20 and $27 \%$ (0$20 \mathrm{~cm}$ ) in coffee areas under agroforestry system after 20 years of implantation, which varied according to the tree species. In this study, the C accumulation rate was estimated between 0.8 and 1.1 Mg C ha' ${ }^{-1}$ year $^{-1}$. 


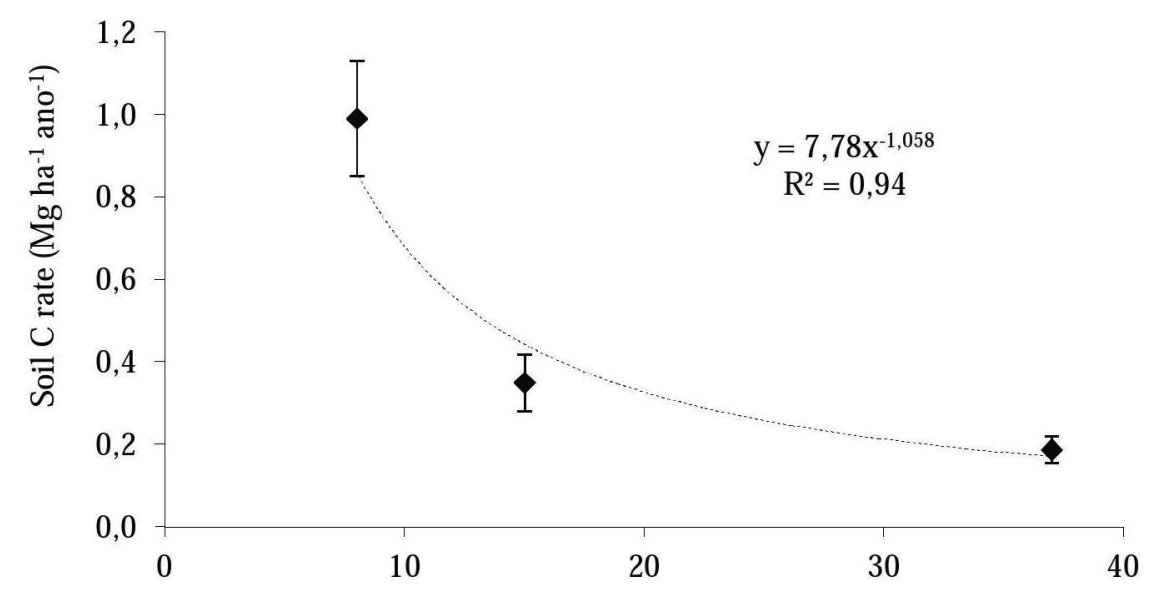

FIGURE 3 - Carbon loss rate $\left(\mathrm{Mg} \mathrm{ha}^{-1}\right.$ year $\left.^{-1}\right)$ in the soil for coffee growing areas with different coffee cultivation times in relation to native savanna vegetation at Boa Vista Farm in the municipality of Patrocínio, Minas Gerais state, Brazil.

The longest implanted area (37 years) showed the lowest loss in $\mathrm{C}$ stocks $\left(0.2 \mathrm{Mg} \mathrm{C} \mathrm{ha}^{-1}\right.$ year-1 ${ }^{-1}$ Figure 3 ) reflecting in dynamic equilibrium, where the $\mathrm{C}$ loss in the system is compensated by the entry of organic material derived from both coffee and phytomass of the invading plant of interlines. This low change rate in soil carbon over time after LUC may be related to the presence of more recalcitrant fractions of the organic material, e.g., organic polymers such as lignin, suberins, resins and waxes (SILVA; MENDONÇA, 2007). In coffee cultivation, the entry of $\mathrm{C}$ in the soil occurs mainly by leaf deposition, mortalities and root exudation. During decomposition, most will be emitted as $\mathrm{CO}_{2}$, while approximately lower than $20 \%$ will remain in the soil (THEODORO; MENDES; GUIMARÃES, 2009).

These results evidence that the higher $\mathrm{C}$ loss rate occurs in the initial cultivation period (Figure 3), i.e., closer to the LUC. However, as discussed previously, the sequence of operations during conversion from native vegetation to farming systems promotes high loss of SOM. Thereby, there is the possibility that the $\mathrm{C}$ loss occurred to the detriment of the LUC and not necessarily from the new farming system. In other words, the coffee cultivation in clayey soil and influenced by the climate of the Cerrado biome reached a steady state, in which the input of organic matter and the decomposition would be in dynamic equilibrium with the mineralization of the SOM. In this respect, there are no changes in the soil $\mathrm{C}$ stocks with the coffee cultivation time (Figure 2A) and therefore the $\mathrm{C}$ loss rate did not change effectively with
LUC time, since the SOM already had been lost and hence the loss rate was only diluted according to the evaluated times.

In the second study, the application of the organic compost increased the soil $\mathrm{C}$ stock by $10 \%$, from 58 to $63 \mathrm{Mg} \mathrm{C}^{-1}$ ( $\mathrm{p}<0.05$; Figure $2 b$ ). Thus, the application of the organic compost in four years showed accumulation rate of 1.15 $\mathrm{Mg} \mathrm{C}$ ha $^{-1}$ year $^{-1}$ in relation to the situation without the compost application. The study by Guimarães et al. (2014) showed a $20 \%$ increase in soil C stock $(0-20 \mathrm{~cm})$ in organic coffee cultivation that received green manure and jack-bean (Canavalia ensiformis (L.) DC.) in relation to conventional cultivation, with 11-year accumulation rate estimated at $1.7 \mathrm{Mg} \mathrm{C}^{-1}$ year $^{-1}$. According to Cerri et al. (2009), the main factors determining the soil $\mathrm{C}$ accumulation or loss rate are the quantity, quality and positioning of the organic matter contribution, as well as weather conditions, soil type (SIQUEIRA NETO et al., 2010), soil management and other cultural practices, besides the time of implantation and maintenance of the cropping system (CORBEELS et al., 2016).

\section{CONCLUSIONS}

The land-use change (LUC) from native vegetation to coffee cultivation reduced soil $\mathrm{C}$ stock by $10 \%$ and, for the present study conditions, it can be verified that soil $\mathrm{C}$ loss occurred due to LUC operations and not by the coffee cultivation; The soil $\mathrm{C}$ loss rate showed that the soil C stock after the losses due to LUC with the cultivation time reached the state in which the 
organic matter contribution and the decomposition are in dynamic equilibrium with the mineralization of the SOM;

The application of the organic compost derived from the coffee processing favored the maintenance and even the increase of soil C stock by $10 \%$ over a four-year period.

\section{ACKNOWLEDGEMENTS}

The authors would like to thank the owner and employees of Boa Vista Farm for the reception, support and information provided to the research team. To Foundation for Research and Scientific and Technological Development of Maranhão and National Council of Technological and Scientific Development (DCR - 03572/2016) for the scholarship to MSN and to the Coordination for the Improvement of Higher Education Personnel (CAPES) for granting a Ph.D. scholarship to MHB.

\section{REFERENCES}

ALCÂNTARA, E. N.; FERREIRA, M. M. Efeitos de métodos de controle de plantas daninhas na cultura do cafeeiro (Coffea arabica L.) sobre a qualidade física do solo. Revista Brasileira de Ciência do Solo, Viçosa, v. 24, p. 711-721, 2000.

BASTOS, L. A.; FERREIRA, I. M. Composições fitofisionômicas do bioma cerrado: estudo sobre o subsistema de Vereda. Espaço em Revista, Goiânia, v. 12, n. 2, p. 97-108, 2010.

BAYER, C. et al. C and $\mathrm{N}$ stocks and the role of molecular recalcitrance and organo-mineral interaction in stabilizing soil organic matter in a subtropical Acrisol managed under no-tillage. Geoderma, Amsterdam, v. 133, p. 258-268, 2006.

BERNOUX, M. et al. Cropping systems, carbon sequestration and erosion in Brazil, a review. Agronomy for Sustainable Development, Les Ulis, v. 26, p. 1-8, 2006.

Modeling vertical distribution of carbon in

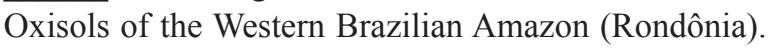
Soil Science, New Brunswick, v. 163, n. 12, p. 941951, 1998.

CERRI, C. C. et al. Brazilian greenhouse gas emissions: the importance of agriculture and livestock. Scientia Agricola, Piracicaba, v. 66, n. 6, p. 831-843, 2009.
COMPANHIA NACIONAL DE ABASTECIMENTO. Acompanhamento de safra Café: v. 3, safra 2016: terceiro levantamento, setembro 2016. Available from: $<$ http://www.conab.gov.br>. Acesso em: 14 nov. 2016.

CORBEELS, M. et al. Evidence of limited carbon sequestration in soils under no-tillage systems in the Cerrado of Brazil. Scientific Reports, London, v. 6, 2016. Available from: <https://www.nature.com/ articles/srep21450>. Acesso em: 10 jan. 2017.

CORTEZ, J. W. et al. Modificação dos parâmetros físico-hídricos do solo sob diferentes sistemas de irrigação na cafeicultura. Revista Brasileira de Ciências Agrárias, Recife, v. 5, n. 2, p. 244-249, 2010.

EMPRESA BRASILEIRA DE PESQUISA AGROPECUÁRIA. Sistema brasileiro de classificação de solos. 3. ed. Rio de Janeiro, 2013. 353 p.

FERNANDES, F. A.; FERNANDES, A. H. B. M. Atualização dos métodos de cálculo de estoques de carbono do solo sob diferentes condições de manejo. Corumbá: EMBRAPA Pantanal, 2013. 5 p. (Embrapa Pantanal. Comunicado Técnico, 95).

FOOD AND AGRICULTURE ORGANIZATION OF THE UNITED NATIONS. Statistics Division. Resource STAT land use data. Available from: $<$ http://faostat.fao.org/site/377/default.aspx\#ancor>. Acesso em: 14 nov. 2016.

GRACE, J. A. et al. Productivity and carbon fluxes of tropical savannas. Journal of Biogeography, Washington, v. 33, p. 387-400, 2006.

GREBIM, F. O. Estoques e qualidade da matéria orgânica em solos cultivados com cafeeiro com diferentes manejos, em regiões de Minas Gerais. 2010. 108 p. Tese (Doutorado em Ciência do Solo)Universidade Federal de Viçosa, Viçosa, 2010.

GUIMARÃES, G. P. et al. Stocks and oxidizable fractions of soil organic matter under organic coffee agroforestry systems. Coffee Science, Lavras, v. 9, n. 1, p. 132-141, 2014.

HERGOUALC'H, K. et al. Changes in carbon stock and greenhouse gas balance in a coffee (Coffea arabica) monoculture versus an agroforestry system with Inga densiflora, in Costa Rica. Agriculture, Ecosystems and Environment, Amsterdam, v. 148, p. 102-110, 2012.

KARP, A. et al. Environmental and climate security. In: SOUZA, G. M. et al. (Ed.). Bioenergy \& sustainability: bridging the gaps. Paris: SCOPE, 2015. p. 138-183. 
LAL, R. Carbon management in agricultural soils. Mitigation and Adaption Strategies for Global Change, Oxford, v. 2, p. 303-322, 2007.

Carbon sequestration. Philosophical Transactions of the Royal Society of London. Series B, Biological Sciences, London, v. 363, p. 815-830, 2008.

MARCHIORI JUNIOR, M.; MELO, W. J. Alterações na matéria orgânica e na biomassa microbiana em solo de mata natural submetido a diferentes manejos. Pesquisa Agropecuária Brasileira, Brasília, DF, v. 35, p. 1177-1182, 2000.

PAUSTIAN, K. et al. Climate-smart soils. Nature, London, v. 532, p. 49-57, 2016.

PAVAN, M. A.; CHAVES, J. C. D. Alterações nas frações de fósforo no solo associadas com a densidade de populacional de cafeeiros. Revista Brasileira de Ciência do Solo, Viçosa, v. 20, p. 251-256, 1996.

RANGEL, O. J. P. et al. Frações oxidáveis do carbono orgânico de latossolo cultivado com cafeeiro em diferentes espaçamentos de plantio. Ciência eAgrotecnologia, Lavras, v. 32, n. 2, p. 429-437, mar./abr. 2008.
SILES, P.; HARMAND, J. M.; VAAST, P. Effects of Inga densiflora on the microclimate of coffee 20 (Coffea arabica L.) and overall biomass under optimal growing conditions in Costa Rica. Agroforestry Systems, Dordrecht, v. 78, p. 269-286, 2010.

SILVA, C. A. et al. Variabilidade espacial e temporal de atributos físicos em solo de cerrado sob cafeicultura tecnificada e submetida a diferentes sistemas de manejo. Horizonte Científico, Uberlândia, v. 1, p. 1-52, 2006.

SILVA, I. R.; MENDONÇA, E. S. Matéria orgânica do solo. In: NOVAIS, R. F. et al. (Ed.). Fertilidade do solo. Viçosa, MG: Sociedade Brasileira de Ciência do Solo, 2007. p. 275-374.

SIQUEIRA NETO, M. et al. Soil carbon stocks under no-tillage mulch-based cropping systems in the Brazilian Cerrado: An on-farm synchronic assessment. Soil and Tillage Research, Amsterdam, v. 110, p. 187$195,2010$.

THEODORO, V. C. A.; MENDES, A. N. G.; GUIMARÃES, R. J. Resposta de lavouras cafeeiras em transição agroecológica a diferentes manejos de solo. Coffee Science, Lavras, v. 4, n. 1, p. 56-66, 2009. 